\title{
UMA DRAMATURGIA HÍBRIDA PARTIR DE PEÇAS NÃO CANÔNICAS DE TENNESSEE WILLIAMS
}

\author{
UNA DRAMATURGIA HÍBRIDA DE PIEZAS NO CANÓNICAS POR \\ TENNESSEE WILLIAMS
}

\section{A HIBRIDY DRAMATURGY FROM NONCANONICAL TENNESSEE WILLIAMS PLAYS}

\author{
Luis Marcio Arnaut de Toledo \\ Universidade de São Paulo - USP \\ sp.vi@hotmail.com \\ $\underline{\text { lmarcio@usp.br }}$
}

\begin{abstract}
RESUMO
A partir do alinhamento de forma e conteúdo das peças Why Do You Smoke So Much, Lily? e Something Unspoken de Tennessee Williams, foi elaborada uma dramaturgia híbrida para a construção de uma cena dirigida pelo autor na Faculdade Paulista de Artes, em São Paulo. Este trabalho analisa a dramaturgia desta cena de direção, ressaltando, a partir das peças originais, a figuração histórica e social da homossexualidade feminina no contexto heteronormativo e seus reflexos na contemporaneidade. Com isso, evidencia-se um autor que deve ser desenraizado dos princípios hegemônicos de realismo psicológico e biografismo para ser relido como uma exposição crítica da sociedade.
\end{abstract}

Palavras-chave: Tennessee Williams. Dramaturgia estadunidense. Homossexualidade feminina. Análise dramatúrgica.

\section{RESUMEN}

A partir de la alineación de la forma y el contenido de las piezas ¿ Why Do You Smoke So Much, Lily? y Something Unspoken de Tennessee Williams, fue desarrollado una dramaturgia híbrida para la construcción de una escena dirigida por el autor en la Faculdade Paulista de Artes, en São Paulo, Brasil. Este trabajo analiza la dramaturgia de esta escena de dirección, destacando, a partir de las obras originales, la construcción histórica y social de la homosexualidad femenina en el contexto heteronormativo y sus reflejos en los tiempos contemporáneos. Con esto, es evidente un autor que debe ser desarraigado de los principios hegemónicos del realismo psicológico y la biografía para ser releído como una exposición crítica de la sociedad.

Palabras clave: Tennessee Williams. Dramaturgia americana. Homosexualidad feminina. Análisis dramatúrgico. 
Artículo. Luis Marcio Arnaut de Toledo. "Uma dramaturgia híbrida partir de peças não canônicas de Tennessee Williams”.

\section{ABSTRACT}

From the form and content alignment of the plays Why Do You Smoke So Much, Lily? and Something Unspoken from Tennessee Williams, a hybrid play was constructed for a scene to be assembled and directed by the author in Faculdade Paulista de Artes in São Paulo. This paper analyzes the dramaturgy of this scene, emphasizing, from de original plays, the historical and social construction of feminine homosexuality in the heteronormative context and its reflections in contemporaneity. With this, it is evident an author who must be uprooted from the hegemonic principles of psycological realism and biografism to be reread as a critical exposition of the society.

Keywords: Tennessee Williams. American Drama. Female Homosexuality. Dramaturgical Analysis.

Recibido: 25 de abril de 2020

Aceptado: 25 de mayo de 2020

\section{Expedientes coincidentes em duas peças em um ato}

As peças Why Do You Smoke So Much, Lily? - A Short Story in One-act [Por que você fuma tanto, Lily? - Um conto em um ato, 1935] e Something Unspoken [Algo não dito, 1958] de Tennessee Williams [1911-1983] foram a base para a construção de um texto para uma encenação com duração de 10 a 15 minutos. A cena foi dirigida pelo autor em 2015 quando cursava a disciplina Teatro Contemporâneo, Direção Teatral e Prática de Encenação, sob a responsabilidade do professor doutor Marcelo Soler na Faculdade Paulista de Artes em São Paulo. A cena e a dramaturgia híbrida foram, também, foco do Trabalho de Conclusão de Curso em Licenciatura em Teatro e, posteriormente, publicado em formato de livro. Esta encenação tinha como objetivo principal abordar a obra de Tennessee Williams sob o viés sócio-histórico, sem se preocupar proeminentemente com os expedientes realista e psicológico, como protocola a leitura tradicional da obra do autor no Brasil.

A proposição é, portanto, investigar como esta dramaturgia interpela o conteúdo social e histórico da mulher homossexual a partir das peças originais e averiguar sua reverberação nos dias correntes, desde que são trabalhos das décadas de 1930 e 1950. As similaridades entre as peças suscitam essa abordagem estética de intersecção, articulando os contextos sociais, políticos e históricos. Sendo assim, as semelhanças observadas entre as duas peças de Williams podem ser elencadas:

- o fato de serem obras não canônicas permite que se estenda a análise dramatúrgica sobre a escrita pouco conhecida do autor, desfocando daquelas mais prestigiadas e 
fartamente cotejadas em análises acadêmicas, por terem sido sempre reconhecidas como sucesso comercial e expostas no mainstream, referência às obras escritas entre 1944 a 1961; - ambas são peças em um ato, portanto, possuem conteúdos condensados, ausência de conflitos evidentes e de desfechos. A matéria principal é a ação situacional, a homossexualidade como mola propulsora das ações seguintes, o que leva a um deslocamento percebido da forma dramática tradicional, evidente quando desfoca os diálogos como única solução de conflitos e desenlaces;

- são observadas características expressionistas no farto uso de simbologia e elipses, com personagens emblemáticas nestas obras. O silêncio é utilizado como metáfora da homossexualidade. Em ambos os casos, a não familiaridade com expedientes simbólicos e do expressionismo poderão levar a uma leitura das personagens como heterossexuais, cujo diferencial é a subjetividade díspar daquela preconizada pela sociedade, ressaltando apenas elementos de rebeldia. Esta interpretação se revela um tanto quanto rasa, pois ignora os princípios da estética expressionista, a contextualização histórico-crítica, costumeiramente negligenciada na leitura hegemônica, e as próprias rubricas do autor;

- refletem o universo feminino: personagens homossexuais oprimidas pela sociedade, sem coragem de assumir sua identidade, e a homossexualidade tratada com ambiguidade. Todavia, as mulheres são colocadas como figuras que rompem com os padrões das mulheres sulistas dos Estados Unidos, não refletindo a figura tradicional da Sourthen Belle. São diferentes daquelas com papéis femininos para o lar, que deveriam, portanto, aceitar a maternidade ou servir como objeto de submissão sexual;

- sob o ponto de vista social, é possível atentar que ambas as famílias delineiam o processo de derrocada da aristocracia no Sul dos Estados Unidos. A forma dramatúrgica se destaca, desde que, com expedientes expressionistas, as personagens com mais idade [Cornelia, de Something Unspoken, e Sra. Yorke, de Why Do You Smoke So Much, Lily?] figuram claramente a própria sociedade opressora; assim como as personagens Lily e Grace [Why Do You Smoke So Much, Lily? e Something Unspoken, respectivamente] representam a mulher subserviente, que se cala perante as exigências da convencionalidade, superando as discussões advinhas de questões de gênero. Com isso, o que de fato existe nas personagens é a aceitação servil do culto às aparências, alternativa que busca proteção 
Artículo. Luis Marcio Arnaut de Toledo. "Uma dramaturgia híbrida partir de peças não canônicas de Tennessee Williams”.

contra a violência social. Com isso, há a necessidade de transcendência de valores sociais e reciclagem de conceitos, pensando na diversidade sexual;

- como elementos históricos para situar as peças política e temporalmente, elas trazem a sociedade representada como manipuladora para suprimir a expressão homossexual ou homoafetiva, lembrando o Ato de Comstock [em vigor desde 1873] e o Código Hays [de 1930 a 1968], leis que proibiam no teatro, literatura, televisão e cinema os temas considerados tabus como a aborto e contracepção, o que na época era considerado obscenidades morais, sexo pré e extramarital, insultos à instituição do casamento, homossexualidade, violência sexual, a mudança do papel da mulher na sociedade e o aumento populacional das classes mais baixas; censuravam beijos, nudez, palavras religiosas, homoafetividade, miscigenação, vícios, gestos e posturas vulgares, entre outros;

- são peças que se alinham estreitamente com os valores contemporâneos. A sociedade, embora evidencie diversas conquistas sociais e tecnológicas, ainda dá sentido à censura e o silêncio em relação à homossexualidade, fomentando uma pedagogia do armário no seio da família tradicional e na sociedade conservadora e teocrata em ascensão no Brasil pós-2016. A supressão da homossexualidade aparece cerceada, conjuntamente à ascensão de um momento político e social com claras e fortes pretensões retrógradas; e

- é importante ressaltar que a abordagem de personagens homossexuais por Tennessee Williams não evidencia heroínas da resistência ou salvadoras da pátria que levantam bandeiras, como os movimentos identitários contemporâneos exigem escancaradamente da cena teatral. $\mathrm{O}$ autor é um observador crítico da sociedade em sua dramaturgia. Embora adornadas com simbologias, suas personagens homossexuais femininas, como todas as outras mulheres de sua vasta obra, são retratadas com diálogos muito próximos do realismo, forma dramatúrgica que evidencia a poética do autor mesclada com questões tão importantes da sociedade - talvez, um dos motivos que sua estilística sempre foi identificada como de realismo psicológico. Em algumas vezes há um tom de paródia, revelando aspectos críticos, o que pode ser, inclusive, lido por aqueles pouco familiarizados com a obra do autor como uma suposta veia preconceituosa, visto a dificuldade de análise dramatúrgica e contextualizações histórica e estética da obra de Tennessee (Toledo 147, 184, 196). O dramaturgo apresenta párias sociais, sem que precisem se destacar ou compor um manifesto, propor uma revolução ou um movimento. A 
Nueva Revista del Pacífico 2020, № 72, (pp. 26-45). ISSN (e) 0719-5176

estilística expressionista e a poesia de Williams faz emergir elementos épico-líricos que possibilitam o distanciamento crítico do público, levando-o a uma reflexão sem precedentes acerca das questões da opressão à mulher homossexual.

\section{A homossexualidade na obra de Tennessee Williams}

Nenhuma outra peça de Williams figura tão claramente a homossexualidade feminina quanto Why Do You Smoke So Much, Lily? e Something Unspoken, como afirma o professor doutor Joe Falocco (1/5) da Theatre Catawba College de Boston, que encabeça o pensamento da organização estadunidense The Tennessee Williams Annual Review, composta hoje pelos mais importantes pesquisadores do dramaturgo nos Estados Unidos. $\mathrm{Na}$ verdade, o que o pesquisador quis deixar claro é que não há indícios da figuração da mulher homossexual em outras peças conhecidas do autor.

Como o conjunto de obras do autor não possui um corpus, está pulverizado em bibliotecas, editoras e com amigos ou descendentes de seus agentes, a cada dia pode surgir repentinamente uma nova descoberta. Por enquanto, Why Do You Smoke So Much, Lily? é, ainda, considerada a primeira peça de Williams a figurar a homossexualidade, juntamente com a peça Summer at the Lake, do mesmo ano, esta focada especificamente na personagem masculina Donald (Thornton 84-85).

A homossexualidade é um expediente que o dramaturgo fartamente utilizou ao longo de sua obra, retratando-a, em especial, após os anos contraculturais da década de 1960 em diante - peças, infelizmente, ainda desconhecidas e inexploradas (Toledo 132). Todavia, sua representação sempre foi disfarçada por diversos elementos em que as personagens, de certa forma, estavam ocultas na dramaturgia, quer seja pelo seu retrato ambíguo ou pela sua ausência no palco. É memorável a remissão às obras para compreender a vasta utilização desta matéria narrativa:

- Tom Wingfield, um de seus personagens masculinos mais famosos, é o homossexual latente para muitos admiradores da obra por simples reflexo autobiográfico. Ao fazer esta rasa afirmação, o que se negligencia é a contextualização histórica da peça The Glass Menagerie [À margem da vida, 1944], em que a retratação da homossexualidade aberta era impensável na dramaturgia estadunidense. Mesmo assim, a ambiguidade sexual 
Artículo. Luis Marcio Arnaut de Toledo. "Uma dramaturgia híbrida partir de peças não canônicas de Tennessee Williams".

da personagem tornou-a não só famosa, mas desejada por atores do mundo inteiro para defendê-la ao palco, elevando Williams ao perfil de celebridade;

- A Streetcar Named Desire [Um bonde chamado Desejo, 1947] traz a personagem Alan, esposo de Blanche, citado apenas quando ela descreve seu suicídio, quando revela ter descoberto o seu segredo;

- em Cat in Hot Tin Roof [Gata em telhado de zinco quente, 1955], a personagem Brick é homossexual e está em cena, embora isso não seja em nenhum momento revelado. Ao contrário, obrigado a manter os padrões exigidos pelos códigos censores, ele acaba tendo seu final reescrito e deixando uma dúvida tremenda sobre sua sexualidade, desde que reata ardentemente com a esposa na cena derradeira;

- o mesmo acontece em Suddenly, Last Summer [De repente, no último verão, 1958], onde a personagem Sebastian é o tempo todo referenciada por todas as outras. Sua morte trágica e as referências à sua homossexualidade são apenas descritas pela prima Catherine. Ele jamais aparece em cena, tal como Alan;

- em Spring Storm [Tempestade de primavera, 1937-38], Arthur tem uma sexualidade que em alguns momentos é descrita ambiguamente, sua extrema sensibilidade parece, em vários momentos, ser uma remissão à homossexualidade;

- em Not about Nightingales [Nada sobre rouxinóis, 1938], há a personagem Queen, muitas vezes ignorada pelas outras, vivendo em uma prisão com homens heterossexuais, muitas vezes ignorada nas relações dialógicas. Tennessee expõe as subjetividades gays em um período em que era impossível sua materialização. Este deve ser, sem dúvida, um dos motivos que levou a peça ficar engavetada por 60 anos, tendo sido levada aos palcos pela primeira vez somente em 1998; e

- em You Touched Me! [Quando você me tocou, 1942], Reverendo Hooker é outra personagem ambígua sexualmente das peças iniciais de Williams, tal como Arthur, fugindo grosseiramente das investidas de Tia Emmy. Sua sexualidade não é nunca discutida pelo dramaturgo e nada fica evidentemente explícito.

Essas são apenas algumas das obras em que Williams figura a homossexualidade, citadas a título de ilustração. Foram escolhidas por dois motivos importantes: as três últimas por estarem absolutamente fora do cânone; e as outras por fazerem parte do corpus 
de seus trabalhos mais prestigiados e, para muitos pesquisadores, críticos de sua obra e artistas, os únicos conhecidos.

A fascinação de Williams a respeito das subjetividades homossexuais sempre o levou à pesquisa literária a fim de interpelar expedientes formais e de conteúdo. Afinal, tanto a sociedade não os aceitaria de pronto quanto a censura os impediria. Havia, portanto, uma ansiedade para descobrir uma maneira para que esta narrativa se apresentasse. Seu maior entusiasmo veio, certamente, do poeta estadunidense modernista Hart Crane [1899-1932]. Em sua poesia ele nunca pôde trazer a homossexualidade à tona, emparelhado com Williams em grande parte de sua carreira, com exceção das obras escritas após a década de 1960, certamente com uma liberdade maior sorvida dos movimentos da contracultura, que revela a expressão de homossexualidade de forma aberta em sua escritura desta fase. O poeta que usava metáforas e símbolos possibilitou, com sua obra autodestrutiva, emblemática e tropológica que Williams tivesse o mesmo influxo. O desejo sexual era substituído pela superficialidade da descrição do corpo, da transcendência espiritual, ou da ocultação da sua verdade, o que para muitos poderá ser subentendido como uma espécie de puritanismo disfarçado na estilística de um dramaturgo rebelde, como faz Nancy Tischler (275-304) em sua clássica obra conservadora. Silêncios, disfarces, morte, ocultação, ausências, elipses, violência e morte são as figuras de linguagem mais utilizadas, portanto, para a [des]figuração da sensibilidade homoerótica, impensável na dramaturgia inicial de Williams - de 1930 até o início da década de 1960.

Por que você fuma tanto Lily? (Williams 45-54; Mister Paradise 117-128) é datada de fevereiro de 1935. Foi publicada no Brasil pela primeira vez em 2011 e teve poucas encenações (Dainezi). O espetáculo Propriedades condenadas, dirigido por Marco Antonio Pâmio, em cartaz em 2015-2016 em São Paulo trouxe a primeira montagem comercial documentada no Brasil, contendo, também, a peça This Property Is Condemned [Esta propriedade está condenada]. A primeira temporada foi com Camila dos Anjos e Ricardo Gelli. Na segunda, o ator foi substituído por Gustavo Haddad. O fato bastante curioso é que Lily foi interpretada pelos atores masculinos, opção estética importante para ressaltar os elementos expressionistas da peça e as questões sexuais da famosa, ainda que apenas nos Estados Unidos, primeira personagem homossexual do autor. 
Artículo. Luis Marcio Arnaut de Toledo. "Uma dramaturgia híbrida partir de peças não canônicas de Tennessee Williams”.

Uma segunda versão foi apresentada dentro do espetáculo Hotel Tennessee, em São Paulo, com direção de Brian Penido e Ana Lys, do Grupo Tapa em 2018-2019. Várias peças curtas foram inseridas nesta encenação. Entre elas uma curiosa versão de Lily, onde a moça andrógena e masculinizada, tal como descrita por Tennessee no texto original, foi descaracterizada de sua homossexualidade e suas qualidades intelectuais, sendo lida como uma mocinha sulista heterossexual confusa e com leves traços rebeldes, bastante identificada com as Southern Belles.

Something Unspoken (Williams 90-96; 27 carros 331-358; Algo 11-18) foi elaborada por volta de 1953, mas foi publicada, juntamente com Suddenly, Last Summer [De repente, no último verão] (Williams 145-222) em 1958 sob o título Garden District [O bairro dos jardins]. Teve duas publicações no Brasil, uma em 1983 - com o título Algo que não é falado - e outra em 2012. Ambas as peças tratam sobre matriarcas do Centro-sul estadunidense às voltas com a homossexualidade. Não se tem notícia que esta peça foi encenada comercialmente no Brasil até o momento.

\section{Análise da dramaturgia da encenação}

O texto híbrido aqui cotejado é composto para uma encenação de duração entre 10 a 15 minutos. Faz remissões de falas importantes dos originais, fragmentando-os, para retratar prementemente a homossexualidade feminina. São investigadas as seguintes características propostas nesta dramaturgia híbrida: título; as personagens que a compõem; as rubricas; trilha sonora; iluminação; projeções; os trechos fragmentados de cada peça e sua relevância; e os diálogos.

\subsection{Título da cena}

A escolha do título não é banal, pois um dos objetivos principais é despertar o interesse do espectador, servindo já para reiterar as entrelinhas ou clarear aspectos de personagens ou do próprio enredo. Por isso, classifica-se o título da encenação aqui examinada como sintético, capaz de expressar as peças originais. Além de reproduzir a mesma designação de uma das peças cotejadas, o que dá uma ambiguidade autoral ao trabalho.

Algo não dito é um título direto e invocativo: o que não é dito nesta peça? A partir dele é possível reflexão e questionamentos importantes para a matéria tratada. 
Desta forma, tem-se a compreensão imediata da matéria abordada, resume o conteúdo e os objetivos, refletindo as opções estéticas formais do texto híbrido: o que não é dito em nenhum momento é a homossexualidade, mostrada por Williams como uma identidade abafada, latente. Isto é reproduzido na cena como forma de manter a estilística do dramaturgo e de focalizar na temática principal. O título remete, ainda, à estilística expressionista de Williams com elipses e contornos para abordar a homossexualidade.

Além disso, a denominação pontua a necessidade de se pensar sobre o dramaturgo como esse desconhecido que precisa ser revisitado, sem negligências dos perímetros sociais. Um dramaturgo que precisa ser repensado a despeito do cânone em que foi erigido.

\subsection{As personagens}

As peças originais possuem duas personagens femininas cada uma e a dramaturgia híbrida elimina a presença física de Lily, trazendo apenas Sra. Yorke de Por que você fuma tanto, Lily? A ausência da moça é um estigma da sua condição: a sociedade conservadora não quer perceber indícios da homossexualidade e, também, de uma mulher que não obedece a tradições de feminilidade, subserviência e subordinação (Betti 2011).

Com Sra. Yorke contracenando sozinha, às vezes voltada ao espectador, às vezes às personagens de Cornelia e Grace, qualquer um pode ser a sua filha e, a matrona figura a própria opressão. Destaca-se, também, o caráter épico da dramaturgia, possibilitando reflexão e compreensão de Lily sem que ela esteja de fato no palco.

Lily é uma personagem que vai além dos estereótipos de gêneros. Até mesmo um ator poderia interpretá-la, sem que com isso perdesse a relevância do texto, remetendo à proposta já referida do diretor Marco Antônio Pâmio no espetáculo Propriedades condenadas, em cartaz em São Paulo, Brasil, em 2015-2016. A opressão sexual sufoca qualquer ser humano, quando se leva em conta a orientação sexual. O oprimido é alvo de crueldade, obrigando-o a viver o que é culturalmente imposto pela sociedade heteronormativa, sendo isto a domesticação dos impulsos inauditos, adulterando a natureza humana para esquecer a autonomia e a dignidade.

Como Lily ansiava pela liberdade de autoexpressão e estava impedida pela mãe [a sociedade] de fazê-lo, esteticamente sua ausência resignifica o oprimido. Desaparece sua figura, mas evidencia o vazio, o silêncio, levando senhora Yorke a fazer perguntas a esmo, 
Artículo. Luis Marcio Arnaut de Toledo. "Uma dramaturgia híbrida partir de peças não canônicas de Tennessee Williams”.

beirando o chamado teatro do absurdo, que leva a uma reflexão existencial sobre como o oprimido deve se sentir neste espaço imperativo institucionalizado.

Em relação às personagens de Algo não dito, Cornelia transparece como dominante em todas as situações, uma figura superior, mesmo quando está no escuro, e não dependente de um homem. Grace, por sua vez, mais passiva e querendo permanecer

reticente, age como uma propriedade de Cornelia. É clara a diferença de classes entre elas. Cornelia faz parte de uma aristocracia falida, decadente, mas que mantém as aparências, inclusive no trato com os empregados.

Quando Cornelia fala ao telefone, Grace se coloca na posição de secretária e se sente desconfortável, inclusive, quando recebe de presente as rosas pelos seus 15 anos juntos. Mesmo assim a comunicação dialógica não evidencia o romance entre elas, embora a simbologia deixe claro esta relação. Grace interrompe o diálogo colocando um disco na vitrola, não quer tocar no assunto, permanecendo, assim, algo que não é falado entre elas. Cornelia, mesmo assim, propõe a conversa, mas oprime a companheira, destacando-se como superior. Ela se coloca em uma posição de patroa e da companheira de tantos anos. Mergulhadas em uma sociedade anacrônica e silenciadora, as personagens são construídas, portanto, com uma forma dramatúrgica que não privilegia palavras, mas as entrelinhas, aquilo que não é dito, o silêncio entre elas.

\subsection{As rubricas e a iluminação}

As rubricas delineiam ações pontuais e direcionam o entendimento dos diálogos, com resgate de orientações do próprio Tennessee Williams das peças originais. A maioria delas se refere à movimentação dos atores, os movimentos, gestos, posições, assinalam também o lugar e, principalmente, direcionam a iluminação, determinando a estética principal da cena.

A primeira rubrica traz uma indicação que define a proposta estética de todo o texto híbrido: "A ação se passa no escuro - a opressão" (Toledo, 1). A cena propõe a escuridão total para criar o clima da opressão. As personagens se fundem na escuridão. As duas histórias se fundem, como se fossem únicas, embora de épocas diferentes. Mesmo porque, agora, elas figuram o momento atual, são reverberações para um público acostumado com heroínas do feminismo, vitoriosas com bandeiras, embora pouco à vontade com a crítica 
social. Essa orientação corrobora com o desaparecimento da personagem Lily e não deixa dúvidas sobre o preconceito contra a homossexualidade, presa no armário.

Os lampiões sugeridos são objetos antigos. Seu uso remete a uma prática tradicional e ancestral. Eles também não têm um nível de iluminamento que possibilite acuidade visual. Cria um jogo na cena. A narração é feita com indicações definidas pela iluminação de lampiões na atriz, mas os diálogos são ditos na escuridão. A narração é construída com frases retiradas na íntegra das rubricas de Williams. Assim, os valores hegemônicos do realismo psicológico em que foi tachado pela crítica tradicional são colocados em jogo, trazendo à tona questões culturais evidentes que precisam de exame. Com a iluminação na narração, questões sociais são expostas como feridas nevrálgicas do sistema burguês heteronormativo. A opressão, portanto, seria um pano de fundo para mostrar o autor. E, à maneira de Williams, ambivalente e redundante.

As rubricas, também, revelam um caráter épico no texto: rubricas originais foram transformadas em falas das personagens, por isso estão na terceira pessoa e os verbos estão todos no tempo passado. Sra. York, que as lê, acaba se tornando uma personagem narradora, portanto.

A ideia é que qualquer luz lançada sobre a matéria tratada na dramaturgia de Williams ainda é muito rudimentar, pouco suficiente/eficiente para compreender a figuração expressionista destas personagens. Há, portanto, muito para refletir sobre a expressão homossexual. Assim, como a expansão da leitura e da compressão das obras do autor.

\subsection{A trilha sonora}

A trilha sonora começa com a introdução da ópera Tristão e Isolda de Richard Wagner, Prelúdio, o que confere um clima de tensão, de algo que precisa ser resolvido mas nunca se resolve. É possível traçar paralelos da música com o enredo:

Os violoncelos enunciam o desejo, esse poderoso sentir que percorre toda a partitura desta ópera, e logo os oboés respondem com a entrega; três vezes se repetem essa pergunta-e-resposta, deixando no ar uma suave dissonância. E vão num crescendo até a explosão do amor sensual. De novo os violoncelos se encarregam de levar adiante o tema apaixonado e lascivo. O tormento do amor proibido, da impossibilidade moral de 
Artículo. Luis Marcio Arnaut de Toledo. "Uma dramaturgia híbrida partir de peças não canônicas de Tennessee Williams”.

concretizar a felicidade, os impulsos sensoriais, a tentativa de sublimação. Nunca a paixão humana mais irrefreável foi tão completamente descrita, tão perfeitamente colocada, tão exatamente exposta quanto aqui. É um crescendo de excitação sem paralelo na literatura sinfônica, prova máxima da genialidade de Wagner. Os episódios musicais se sucedem, cada vez mais acima, como se fosse possível ganhar os céus (Fonseca).

Esta música traz à tona o tormento das personagens que não podem realizar moralmente sua natureza homoafetiva, que devem internalizar as pulsões sexuais, freando desejos, sublimando vontades, deslocando sentidos e não expondo o que pensam e thes interessam. A música não denuncia o desejo nem faz paixões explodirem, mas mergulha na dor dos afetos secretos do armário. A música deixa, portanto, clara a relação homoafetiva que, no texto original, está ocultada.

A música final, Somos quem podemos ser de Humberto Gessinger, da banda Engenheiros do Hawaii, faz um contraponto com todas as questões expostas por Tennessee Williams e indica um mundo novo que poderá surgir. O eu lírico diz que recebeu as chaves de uma prisão. As chaves são a consciência livre que permite a abertura do armário. Dessa forma, ele percebe esse outro mundo, diferente das imposições sociais que o negam: "Um dia me disseram/Que as nuvens não eram de algodão/Um dia me disseram/Que os ventos às vezes erram a direção". Com esse despertar, ele percebe o ambiente de fato: "E tudo ficou tão claro/Um intervalo na escuridão". Ele se assusta com o mundo que vê: "Uma estrela de brilho raro/Um disparo para um coração". Identifica os culpados, lançando mão de uma visão crítica: "nós todos temos um pouco de culpa". E, com isso, há certa esperança, não conformista, uma autoaceitação: "somos quem podemos ser, sonhos que podemos ter" (Engenheiros 2019). Um desenlace que se contrapõe a Tennessee Williams, que não deixou evidências otimistas sobre mudanças sociais em relação à homossexualidade ou à construção social do papel da mulher.

Seguindo uma tendência contemporânea de levantar bandeiras contra a violência aos oprimidos e minorias, a encenação acena positivamente com uma performatividade que flerta com documentos iconográficos nas projeções finais.

\subsection{As projeções}


Projeções são recursos documentais, performativos e épicos. Avulta a proposta analítica sobre a condição da mulher indo além das questões ligadas à sexualidade. Manifesta os contextos sociais e políticos no qual a mulher é vista em diversas culturas, o quanto ainda se faz necessária a reflexão sobre o papel da mulher na sociedade e em soluções para a violência feminina.

As fotos expostas de mulheres subjugadas em diversas culturas em um silêncio incomodativo faz uma ponte com o que não é dito, mas está nestas obras de Williams, criando um clima de reflexão - o distanciamento.

As fotos das colegas de turma do autor expostas ao final da projeção em situação de afeto apontam para um risco cênico e, ao mesmo tempo, refrescam a tensão do silêncio pelas fortes imagens. Todavia, fortalecem a música de Humberto Gessinger - que começa no meio das projeções - por se contrapor ao final absolutamente ferrenho e negativo do texto e da opressão, embora profundamente crítico sobre a condição feminina. Evidencia aí a contemporaneidade de Williams, que se comunicará com essas mulheres que já podem lutar pela igualdade e respeito.

Em relação ao risco que as fotos oferecem, é que o espectador poderá ter reações subjetivas perante a imagem de suas colegas, trazendo julgamentos pessoais à tona, sem que consiga uma leitura objetiva da experiência estética que a cena se propõe. O que de fato ocorreu, revelando um público extremamente burguês, conservador e preconceituoso, embora se tratasse de alunos de teatro de uma metrópole cosmopolita como São Paulo.

Assim, revela-se um caráter performático na encenação, trazendo uma cena mais documental, de denúncia e revelação de episódios reais inseridos na cena. Tendo motivos épicos, o objetivo premente é o da reflexão do espectador. Ultrapassa, assim, a representação cênica, propriamente dita. A repercussão do político e do estético nas encenações de Erwin Piscator acontece em função da combinação entre o drama e os documentos, entre as particularidades do palco e as forças históricas. A fusão desses signos reais e representacionais nesta encenação cria, portanto, uma dose de performance caracterizada pela inserção de ações de presentificação em busca da atualidade e da conscientização, levemente inspirada no teatrólogo e encenador alemão.

\subsection{A composição da cena}


Artículo. Luis Marcio Arnaut de Toledo. "Uma dramaturgia híbrida partir de peças não canônicas de Tennessee Williams".

A cena tem quatro partes distintas, sendo que a primeira é um trecho de Por que você fuma tanto, Lily? com Sra. Yorke e a narração feita por Grace e Cornelia.

$\mathrm{Na}$ primeira frase de Sra. Yorke é possível reconhecer traços de homofobia ao associar o cigarro ao comportamento dissociativo feminino de Lily. Apontando lesões físicas na filha, ela diz que isso levará a garota à ruína de sua integridade física e de sua sanidade. Logo depois sugere que Lily "comece pelo tricô" (Toledo, 1; Williams, Mister Paradise 120), uma atividade feminina estereotipada. Termina dizendo que a filha deve deixar de ser diferente das moças de sua idade e tempo, ressaltando que ela será aceita se tiver um comportamento padrão: casando-se com um homem rico para salvar a família do desastre econômico. Esta personagem figura superfícies da aristocracia branca, anglo-saxã e protestante. Isso rememora à designação do grupo holandês WASP ligado à religião protestante e ascendência britânica que supostamente detêm excessivo poder econômico, político e social na sociedade estadunidense com certos privilégios sociais. WASP é o acrônimo pejorativo que diz respeito às pessoas brancas-anglo-saxãs-protestantes.

Senhora Yorke ajeita o cabelo ondulado artificialmente e mostra sua preocupação com as aparências sociais. Mas, ao dizer que o busto caído arfava desenha-se a figuração da sociedade com características de decadência, ultrapassada e desprovida de aparência estética.

As frases para definir Lily são objetivas e fortalecem a ideia de sua homossexualidade. Lily não seguia os modelos impostos pela sociedade - sua mãe é claramente a figuração destes padrões sociais.

Senhora Yorke: Por que você fuma tanto, Lily? Isso te deixa apática. Está acabando com sua pele! Lily, você está ficando pálida! Olhe para os seus dedos, Lily! Meu Deus! Mancha de tabaco em todos eles. Lily! Lily! Por que você fuma tanto? Está destruindo seus nervos! É por isso que está sempre irritada.

Grace: Lily não ouvia a mãe. (iluminada)

Senhora Yorke: Você poderia começar pelo tricô, é mais útil.

Grace: Senhora Yorke ajeitou o cabelo ondulado artificialmente mostrando uma satisfação pretensiosa. Seu busto caído arfava. (iluminada)

Cornelia: Lily não era a perfeita solteirona resignada, para a decepção de Senhora Yorke. (iluminada)

Grace: Lily não tinha mais idade para procurar marido. (iluminada) 
Nueva Revista del Pacífico 2020, No 72, (pp. 26-45). ISSN (e) 0719-5176

Senhora York: Escute aqui, mocinha, você tem que se livrar desse seu complexo de velha solteirona! (Toledo, 1).

Seguindo, o trecho é retirado de Algo não dito com suas personagens e Sra. Yorke como narradora, invertendo os papeis. Cornelia começa querendo quebrar o silêncio sobre o segredo entre as duas e do isolamento no armário. Cornelia também é colocada como narradora para mostrar seu sentimento, retificando que não quer revelar-se, correr o risco de ser desconsiderada como normal ou incapaz de convencionalidades. Na narração de Sra. Yorke, deixa claro que Grace procura fugir da companheira. Tem-se, portanto, um momento épico; cria a expectativa para saber o que é que precisa ser revelado, mas quando a personagem vai dizer, a cena é cortada. A frase final de Grace, citação do poeta e dramaturgo neoclássico inglês William Congreve [1670-1729], é uma explosão de alívio. Assim, não negligencia a citação poética, marca registrada da obra de Williams. Ela revela que o silêncio, aparentemente irrelevante, é motivo de tensão, de sentimentos endurecidos. Ela se refugia na música para buscar alento sobre seu sofrimento íntimo, criando uma quebra aristotélica na ação e evidenciando um momento de reflexão crítica; ao mesmo tempo em que usa a música para cortar os diálogos e criar distanciamento do espectador, intercalando com a narração de Sra. Yorke. Ambas são características épico-líricas de Williams trazidas à cena híbrida.

Cornelia: Diga algo, Grace?

Grace: Eu não disse nada. Eu não ouvia Cornelia. (iluminada)

Cornelia: Gostaria que eu dissesse?

Grace: Com licença, eu... (saindo)

Cornelia: Aonde você vai?

Sra. Yorke: Ela não sabia para onde ir. Ela inventou um lugar. Ela queria fugir para esse lugar inventado. (iluminada)

Grace: Acabei de me lembrar que preciso tomar minhas gotas de beladona!

Cornelia: Ultimamente você tem fugido de mim como se eu te ameaçasse com uma faca. Você foge sempre quando algo é quase - dito - entre nós! (Grace iluminada) Qualquer coisa para evitar uma palavra entre nós. Qualquer coisa para fugir de uma conversa - Qualquer coisa, Grace.

Grace: Eu gosto de Landowska - aquela cravista polaca! Que tal? Isso não suaviza as coisas? 'A música tem encantos que acalmam o coração selvagem.' (iluminada) (Toledo, 2-3)

Sra. Yorke, revigorando a imagem da sociedade opressora, impõe o casamento como única saída para a crise financeira e a falência familiar. Os conceitos enraizados em sua fala 
Artículo. Luis Marcio Arnaut de Toledo. "Uma dramaturgia híbrida partir de peças não canônicas de Tennessee Williams".

mostram que o interesse da sociedade não é a subjetividade dos seus indivíduos, mas a manutenção do stablishment, das convenções e da heteronormatividade.

Senhora Yorke: Qual mãe não deseja que sua filha se case? O que mais você pode fazer? Do jeito que as coisas andam hoje em dia...

Grace: O dinheiro acabou. Tudo acabou. A família acabou, o sonho acabou. O paraíso acabou. Tudo falido. (iluminada)

Senhora Yorke: O melhor que se tem a fazer é arranjar um -

Cornelia: Definitivamente, Lily não era uma mulher que se casaria com um... (iluminada) (Toledo, p. 3-4)

Ao mesmo tempo em que Grace se mostra feliz com o presente que ganha de Cornelia pela comemoração dos 15 anos passados juntos, também, revela um desconforto com a necessidade do sigilo. Faz de tudo para escapar da posição de companheira de Cornelia, para a cômoda e opressiva situação de empregada, paradoxalmente. Ela verbaliza isso quando diz: "Às vezes, os pedidos de uma patroa são difíceis de distinguir de ordens" (Toledo, 4; Williams, Mister Paradise 351). Cornelia, no entanto, quer que as duas conversem abertamente sobre o que não pode ser revelado, mas deixa claro que a presenteia muito mais por ela ter permanecido em silêncio, "o silêncio vale ouro" (Toledo, 5; Williams, Mister Paradise 349), nos quinze anos de relacionamento. Tennessee faz uma remissão, portanto, a Oscar Wilde [1854-1900] ao expor o amor homossexual, quando, ao se defender em seu primeiro julgamento em 26 de abril de 1895, refere-se à homoafetividade como sendo "o amor que não ousa dizer seu nome" (Wilde). Um romance, portanto, julgado e condenado a permanecer preso, às escondidas, ao rememorar o literato inglês.

Grace: Uma rosa? A quem devo agradecer esta adorável rosa? À minha generosa - patroa?

Cornelia: Você encontrará mais quatorze na sua escrivaninha na biblioteca.

Grace: Mais quatorze rosas?

Cornelia: Um total de quinze!

Grace: Por que quinze?

Senhora Yorke: Grace já estava com Cornelia há quinze anos! (iluminada)

Grace: Que jeito encantador de se - referir à - ocasião... 
Cornelia: (em direção à Grace) Primeiro pensei "pérolas", depois pensei, Não, rosas. Mas, talvez eu devesse ter dado algo de ouro, há, há! - O silêncio vale ouro, dizem! (a música silencia) Sente-se! Não saia daqui.

Grace: (fugindo de Cornelia) Às vezes, os pedidos de uma patroa são difíceis de distinguir de ordens.

Cornelia: Você não sente que há - algo não dito entre nós? (Grace iluminada)

Senhora Yorke: Não sentia! Não devia sentir. (iluminada)

Cornelia: Eu sinto que há muito tempo há algo não dito entre nós. (Grace iluminada)

Sra. Yorke: Haverá sempre algo não dito entre duas pessoas. Mas, não existem muitas coisas não ditas sem motivo? (Toledo, 5, destaques do autor)

Ao terminar a cena, as falas de Grace, Cornelia e Senhora Yorke se integram sem destruir a estrutura das peças originais, mas seguindo uma nova direção. Não há aqui a busca de um desfecho. O que se procura na conclusão é fortalecer a ideia de que a sociedade impõe protocolos e, assim, oprime aqueles que não se enquadram neles. Deixa claro que, valorizando o silêncio institucionalizado, a relação entre as duas mulheres será apenas de patroa e empregada, identificando Grace como a oprimida. Para reafirmar a ideia, Sra. Yorke repete a reclamação sobre o cigarro e as mazelas que ele traz a Lily e termina identificando apenas a fumaça e as cinzas do cigarro, visualizando apenas o desmembramento da filha homossexual de sua família/sociedade, por não servir convenções. A repetição aqui é mais um recurso épico-lírico utilizado para fortalecer as reflexões. A homossexualidade é associada, portanto, a um vício e aos danos que ele traz, como se fosse o próprio cigarro. Lily seria a ralé, sem valor para salvar financeiramente a família.

Senhora Yorke: Por que você fuma tanto, Lily? Está acabando com sua pele! (silêncio) Mancha de tabaco em todos os dedos. (silêncio) Fumando, fumando, fumando! O tempo todo, Lily!

Cornelia: Como você foi cega em não ver o quão desesperadamente eu Senhora Yorke: Por quê, Lily?

(Cornelia iluminada)

Grace: (em direção à Cornelia) Você é tão forte e sábia. Tem sua riqueza! Sua - fortuna! Seus móveis, ações, a mansão, sua secretariazinha - seus jardins suntuosos...

Cornelia: Eu apenas sinto que há algo não dito entre nós que precisa ser dito... 
Artículo. Luis Marcio Arnaut de Toledo. "Uma dramaturgia híbrida partir de peças não canônicas de Tennessee Williams”.

Senhora Yorke: (percorrendo e iluminando a plateia) Você continua fumando eternamente! Fumando, fumando, fumando! O tempo todo, Lily! A casa está completamente infestada de fumaça e cinza. (Toledo, 6)

Aqui é possível rememorar a peça Ralé de 1901, de Maksim Górki, cujo título tem a tradução mais para a versão francesa Les Basfonds do que para o original La Dnie [em tradução literal No fundo] (Górki). O dramaturgo russo expõe vagabundos e esquecidos que se confrontam em um porão de uma pensão. É uma peça sobre a amargura e o desejo da não realização; onde as personagens procuram algo, desejam estar em outro lugar e seu encorajamento é o desprezo à miséria financeira e moral. A comparação de motivações das personagens das peças de Górki e Williams torna-se pertinente, portanto, para entender que todas elas buscam a plenitude existencial, o que é evidenciado principalmente com o uso da música de Humberto Gessinger.

\section{A problematização da mulher a partir do recorte social}

A construção épico-lírica e documental de uma cena a partir de Por que você fuma tanto, Lily? e Algo não dito evidencia uma concordância entre elas, a partir do retrato da mulher homossexual e sua quase total alienação e opressão na sociedade heteronormativa. É possível realizar recortes representativos de crítica social na dramaturgia, sem violentar as obras de Williams e sua estilística, utilizando os mesmos diálogos e as rubricas complementares. Assim, características das duas peças foram possíveis ser observadas na dramaturgia híbrida. A ambientação sócio-histórica e sua crítica são reveladas, portanto, a partir dos elementos que a compõe e da proposta de encenação. Distancia-se, com isso, da leitura hegemônica de sua obra, psicologizante e autobiográfica, desde que uso de metáforas e alegorias revelam expedientes que explicitam o expressionismo. $\mathrm{O}$ mesmo acontece com as características épicas e, também, do que foi chamado teatro do absurdo.

As sugestões de trilha sonora e iluminação reforçam as imagens alegóricas da crítica tennessiana, fortalecendo os caráteres expressionistas, documental e épico. Isto fica evidente na incomunicabilidade entre Grace e Cornelia, assim como de Sra. Yorke com uma Lily invisível, personificada no público, entremeando a narração. Seus diálogos não possuem interação e interlocutor, sendo que os cortes de Grace funcionam como um distanciamento importante para a reflexão sobre a homossexualidade implícita. 
Nueva Revista del Pacífico 2020, No 72, (pp. 26-45). ISSN (e) 0719-5176

Evidenciadas estas problematizações sociais e históricas da mulher, é possível pontuar que as personagens lidam com esses problemas sem redenção, o que remete à situação típica da peça em um ato, na qual não há mudança possível, mas apenas a certificação de que tudo fica no mesmo lugar. Com uma estreita ligação com o teatro pósdramático praticado nos palcos brasileiros na contemporaneidade, pode-se dizer que a obra de Tennessee tem uma perfeita sinergia com esta estética e poderá ser adaptada ou inspirar obras em que a estilística do autor não sofra e, ao mesmo tempo, comunique-se com plateias acostumadas avidamente com a fragmentação e a liquidez da modernidade.

O texto híbrido traz à tona o quanto o teatro de Tennessee Williams deve ser tirado do cânone no qual foi situado, para evidenciar exposições críticas e históricas da época em que viveu, indo além do realismo psicológico.

\section{Referências}

Betti, Maria Silvia. "Mr. Paradise and Other Plays, de Tennessee Williams: Apontamentos para uma Análise Formal." Literatura e Sociedade, 15 (2011), 94-121. www.revistas.usp.br/ls/article/download/64548/67193

Dainezi, Danilo. Marco Antônio Pâmio mistura peças de Tennessee Williams para falar de personagens marginais. Cultura FM, 12/11/2014. Julio de 2015. http://culturafm.cmais.com.br/radiometropolis

Engenheiros do Hawaii. "Somos quem podemos ser". Septiembre de 2019 https://www.letras.mus.br/engenheiros-do-hawaii/12899/

Falocco, James. "Gardens of Desire: Towards a Unified Vision of Garden District." The TennesseeWilliams Annual Review, 7 (2005). Julio de 2015. http://www.tennesseewilliamsstudies.org/journal/work.php?ID=60

Fonseca, Rafael. (1863) Wagner prelúdio e "Morte de amor" de "Tristão e Isolda". Noviembre de 2015. http://guiadosclassicos.blogspot.com.br/2013/08/1863-wagnerpreludio-e-morte-de-amor-de.html

Górki, Máximo. "Ralé”. São Paulo: Em Cartaz/Veredas, 2012. 146 p.

Thornton, Margareth. (Ed.). Notebooks - Tennessee Williams. 2006. 828 p.

Tischler, Nancy. Tennessee Williams: Rebellious Puritan.1961. 319 p.

Toledo, Luis Marcio Arnaut. O Tennessee Williams desconhecido e experimental de seis peças em um ato das décadas de 1960 a 1980: Abordagem, análise e contexto das 
Artículo. Luis Marcio Arnaut de Toledo. "Uma dramaturgia híbrida partir de peças não canônicas de Tennessee Williams”.

personagens femininas. 417 p. Tese (Doutorado em Artes Cênicas) - Escola de Comunicação e Artes, Universidade de São Paulo, São Paulo, 2019.

Toledo, Luis Marcio Arnaut. Tenesse Williams: Algo não dito - Cena de direção. Ed. Giostri, 2015 [digitado].

Wilde, Oscar. Oscar Wilde - "Eu sou o amor que não ousa dizer seu nome". Septiembre de 2019. https://literatus.blogspot.com/2008/11/o-amor-que-no-ousa-dizer-o-nome-nesse.html

Williams, Tennessee. 27 carros de algodão e outras peças em um ato. 2012. 358p. . 27 Wagons Full of Cotton and Other One-act Plays. 1966. 99 p.

. “Algo que não é falado". Cadernos de teatro- O Tablado, 99, out/nov/dez (1983), 11-18. Julio de 2015, http://otablado.com.br/wp-content/uploads/notebookstheater/a0178c55c41d122bfa3c86a106cbad88.PDF

. Why Do You Smoke So Much, Lily? - A Short Story in One-act. "Mister Paradise and Other One-act Plays." 2005. 245p. Mister Paradise e outras peças em um ato. 2011. 180 p. 